\title{
Analysis on the Value of Integrating the Spirit of Beidahuang into the Cultivation of Mass Entrepreneurship and Innovation Talent Training in Chinese Universities
}

\author{
Yingce Zhan, Yanyan Chen, Jun Li, Yuan Yuan, Mingcong Zhang*
}

Heilongjiang Bayi Agricultural University, Daqing 163319, China

DOI: $\underline{10.36347 / \text { sjebm.2020.v07i02.002 }}$

| Received: 08.02.2020 | Accepted: 15.02.2020 | Published: 18.02.2020

*Corresponding author: Mingcong Zhang

Abstract

Review Article

The 19th National Congress of the Communist Party of China proposes speeding up the construction of an innovative country, and colleges and universities assumed the important task of talent training. Under the new situation, colleges and universities should raise their understanding, integrate their strength and improve their mechanisms, constantly explore innovative and entrepreneurial education models, strengthen innovative and entrepreneurial education, and train top-notch innovative talents. Starting from the scientific connotation of Beidahuang, this paper analyzes the value and important role of integrating the spirit of Beidahuang into the cultivation of mass entrepreneurship and innovation talents and seeks ways and methods for the cultivation of mass entrepreneurship and innovation talents.

Keywords: The Spirit of Beidahuang; Mass entrepreneurship and Innovation; Innovation Talent Training.

Copyright @ 2020: This is an open-access article distributed under the terms of the Creative Commons Attribution license which permits unrestricted use, distribution, and reproduction in any medium for non-commercial use (NonCommercial, or CC-BY-NC) provided the original author and source are credited.

\section{INTRODUCTION}

The Nineteenth National Congress of the Communist Party of China accurately grasped the development trend of the country, Proposed Accelerating the Building of an Innovative State. Innovation is the first driving force leading the development and the strategic support for building a modern economic system[1]. Innovative countries refer to technological innovation, taking scientific and technological innovation as the endogenous motive force of national development to stimulate economic development, to enhance the competitive advantage.

Promoting the construction of innovative countries cannot be separated from the cultivation of high-level innovative talents. Colleges and universities undertake the important task of cultivating all kinds of outstanding talents with the historical mission and social responsibility, full of innovative spirit and practical ability. In a speech at the summer Davos forum in September 2014, Prime Minister Li Keqiang proposed that a new wave of "mass entrepreneurship" and "grassroots entrepreneurship" should be launched on 9.6 million square kilometers of land, forming a new trend of "mass innovation" and "everyone innovation". He hopes to inspire the nation's entrepreneurship and innovation genes[2]. At present, the international and domestic situation is undergoing profound changes, mass innovation and mass entrepreneurship are the needs of social development; Maslow's hierarchy of needs theory suggests that the highest human need is the need for development and the realization of selfworth by giving full play to one's personal intelligence. It shows that innovation and entrepreneurship are also the needs of college students' growth and development. Higher education should meet the needs of social development and the growth of college students to the maximum extent, not only to spread knowledge and culture, but also to cultivate "mass entrepreneurship and innovation" talents who can lead the social development and scientific and technological progress.

\section{The Scientific Connotation of the Spirit of Beidahuang}

The Beidahuang refers to the vast barren areas of the Nenjiang river basin, Heilongjiang river basin and Sanjiang plain in Heilongjiang province. More than half a century ago, the place of the Beidahuang was the wilderness, sparsely populated, densely forested, swampy, haunted by wild beasts in the woods, and lowaltitude birds fly. One of the most valuable resources of the Beidahuang is the black soil, which has about 10 times the organic matter content of loess, deep humus and rich black soil layer, rich fertile and suitable land for farming. This is one of the world's three black-earth regions, accounting for one-fifth of the global blackearth area. After half a century of reclamation, the 
Beidahuang became a national important commodity grain base with an annual output of 7 billion $\mathrm{kg}$, such as soybean production accounts for $30 \%$, corn production accounts for $45 \%$, and rice production accounts for $25 \%$ of the country's total output. The Beidahuang has an irreplaceable place in China,

In the 1950s and 1960s, the spirit of Beidahuang was formed during the development and construction of 100,000 troops, 120,000 border youths, 540,000 intellectual youths and other builders of reclamation areas. The spirit of Beidahuang including many elements of youth growth, such as theory, quality, morality, will, personality charm was a good idea and a good style of work formed [3]. In the different periods of development, construction and development with the Beidahuang, there were demobilized soldiers, youths, intellectuals, and scientific and technological personnel from 28 provinces and municipalities, which marched to the barren land of the grass. In the first start-up of pioneering period with the Beidahuang, the pioneers did not have the material condition and the external mechanical force, however, more than 100,000 demobilized soldiers, under the instructions of the Party Central Committee and Chairman Mao, came to the Beidahuang with no people, no food, and extremely bad environmental conditions, but with fertile soil, vast and developed land. The first generation of pioneers with tenacious consciousness to conquer the bitter cold or torrid heat, stand on one's own feet, the enterprise with painstaking efforts, so that the Beidahuang has undergone earth-shaking changes. The pioneers inherited the people's liberation army's hardships and struggle, their youthfulness and blood were dedicated to the black land of the Beidahuang. In the early stage of socialist modernization, Zedong Mao presents important instructions, "It is necessary for the educated youth to go to the countryside and receive the reeducation of the poor and uneducated peasants" [4].

The reclamation army with young intellectuals, local cadres and peasants not only produced a lot of food for the country but also brought urban cultural deposits and injected fresh blood. The construction of the Beidahuang had become the highest level of modernization and the highest commodity rate of commodity grain production base in China, Chinese people call it Berdacang, and provided the inexhaustible impetus to strengthen Beidahuang. During the second development and construction of the reform and opening-up period, hundreds of thousands of educated urban youth working in the countryside returned to the city after more than ten years of pioneering efforts, and the development of the Beidahuang faced unprecedented challenges.

However, their children shouldered the important task of building modernization under inspired by the strong spirit with the Beidahuang pioneers of the first and second generations [5]. The new generation of the Beidahuang people dared to face the market, meet the challenge, push the times forward, deny and open up under the realization of the ideal entrepreneurial practice, such as Jing Zuo is a good daughter of the Beidahuang pioneers, Yirong $\mathrm{Xu}$ is a father of the Beidahuang rice, and so on. The spirit of Beidahuang constantly enriched and practice with the Beidahuang people, and guided the spirit to become better. Many builder's souls remained forever in the black land with reclaim wasteland and entrepreneurship, they practiced the pledge by giving the whole life and their children and grandchildren for the development with the Beidahuang.

Although the spirit of Beidahuang originated from the characteristic period of the development and construction of the Beidahuang, and was the concentrated embodiment of the national spirit with the specific people, it was homologous and synchronous development with the cause of farming and reclamation in China. In the early 1990s, the Party Central Committee concentrated on the understanding and wisdom of the Beidahuang people, the basic connotation with the spirit of the Beidahuang is summarized as follows: painstaking efforts of pioneering spirit, the innovative spirit of daring to open, the unity spirit of pay attention to the interest of the whole, the service spirit of selfless dedication. The national spirit was forged by the Beidahuang people for generations with life and youth, and the spirit of the Beidahuang still exudes inexhaustible vitality and has strong vitality in the new period of China.

\section{The pioneering spirit of Painstaking efforts is a source of strength for mass entrepreneurship and innovation talent}

The spirit of painstaking efforts is an essential spiritual strength for entrepreneurship officers, It is not only an important part of the spirit of Beidahuang but also an important part of the spirit of the Chinese nation. The spirit of painstaking efforts is the spirit of hard struggle embodied by individuals or groups in the pursuit of their goals, the determination to overcome all difficulties, and even the state of mind without fear of sacrifice. It is the spirit of hard struggle embodied by individuals or groups in the pursuit of their goals, the determination to overcome all difficulties, and even the state of mind without fear of sacrifice. The history of the development of the Chinese nation is the history of the hard struggle of the children of all ethnic groups. Whether it was the period of China's liberation war, or the development and construction of the great famine and socialist modernization construction, the Chinese nation is relying on this spirit to go through the vicissitudes of life and stand among the nations of the world.

Integration of the hard-working the Beidahuang spiritual forces into the mass entrepreneurship and innovation talent training process. 
It is not only the inheritance of the red gene of the Chinese sons and daughters but also the inevitable requirement of the new era and the realization of the self-worth of the young people. In the history of the Great Northern Famine, there have been a number of people who share the worries that the country is not full of food and clothing。Ex-soldier Zengxue Ren risked his death to rescue a tractor trapped in a quagmire; To open up this wilderness, Colonel Zhenrong Huang 9 toes frozen to death, it wasn't discovered until he died. The youth represented by them are determined to devote their youth and intellectual wisdom to the development of the motherland. They in the hardworking pioneering years, let their own growth process produced rich social value. Their efforts have laid the seeds of hope for the development of the Beidahuang. These historical imprints provide a historical basis and factual reference in mass entrepreneurship and innovation talent training. It has important spiritual support for young people to set up lofty aspirations. The study and understanding of the Beidahuang spirit is the effective channel and focus of inheriting the hardworking entrepreneurial spirit.

The innovative spirit of daring to open up is the inexhaustible driving force for cultivating mass entrepreneurship and innovation talents

Since China's reform and opening up in 1978, the Communist Party of China has united and led the people of all ethnic groups throughout the country to emancipate the mind, seek truth from facts and explore a new path for the development of socialism with Chinese characteristics. Since the 18th National Congress of the Communist Party of China, the Party Central Committee with Jinping $\mathrm{Xi}$ as the core has solved many problems that have been long wanted to be solved but have not been solved, and has accomplished many major events. China has made historic changes and brought new vitality and vitality to our socialist system. All these reforms and progress are based on the innovative spirit of daring to open.

Before China's reform and opening up, the national farming and reclamation system lost money for 12 years. In this context, the Beidahuang began the second development. The Beidahuang Reclamation area challenges the traditional management system, establishes the family farm, implementation of the household contract responsibility system, has embarked on the new development road. After China's reform and opening in 1978, the Beidahuang Reclamation area with fresh vitality embarked on the development of modern agriculture centered on mechanization. This courage to deny, the Beidahuang spirit of daring to open is a new era young people innovation, entrepreneurial struggle torches, forward lighthouse. The power of the Beidahuang spirit resonates with the development of youth. Therefore, in the process of cultivating mass entrepreneurship and innovation talents, we can make good use of the power of the Beidahuang spirit to guide college students to face setbacks and difficulties.

The unity spirit of pay attention to the interest of the whole is the value criterion for training mass entrepreneurship and innovation talents

In 1960, when China encountered natural disasters, rations in the Beidahuang Reclamation area were rapidly reduced, with $7.25 \mathrm{~kg}$ of workers and 5.5 $\mathrm{kg}$ of workers' families per month[6]. Under such conditions, the Beidahuang Reclamation completed its export mission of 30 million kilograms of soybeans and handed over 180 million kilograms of grain to the state. Throughout the history of China's development, no matter the period of the Long March, the period of development and construction of the Beidahuang, the period of resisting floods in 1998 and the period of resisting SARS, all cannot be separated from the strength and wisdom of the collective.

Why can we get through one difficulty after another? Because a lot of people sacrifice themselves and pay attention to the interest of the whole. Why do we integrate the unity spirit of pay attention to the interest of the whole into the mass entrepreneurship and innovation talent training process? China's future is in the hands of young people. When there is a conflict between national interests and individual gains and losses whether young people can establish the right values.

Since the founding of the Communist Party of China, the realization of communism has been regarded as the highest ideal and goal of the Party. Jinping Xi said, "The realization of communism is the highest ideal of our Communists, and this highest ideal needs to be fought from generation to generation"[7]. The history of the Beidahuang development and the example in the process of development have a strong incentive and guidance for the growth of young people. Young people should not only establish a sense of innovation and entrepreneurship with a strong sense of mission, but also shoulder the heavy responsibility of the development of the times with a strong sense of responsibility, and closely combine the development of the individual with the fate of the country.

The service spirit of selfless dedication is the spiritual support for the cultivation of mass entrepreneurship and innovation talents

In the course of the development and construction of the Beidahuang, there are 100,000 graduates of colleges and universities,200,000 young people to support border construction and 540,000 urban intellectuals. The moment they choose to go to the Beidahuang, it means risk and pay. What forces have brought people from all over China together in this deserted land? The answer is the spirit of selfless service, guided by this spiritual force, they volunteered to work wherever they needed to build their country ; 
The answer is the spirit of selfless service, let these people dedicate their youth, their lives and their children. The service spirit of selfless dedication is the oath of the Beidahuang, and it is the shining place of the spirit of the Chinese nation.

Under the background of mass entrepreneurship and innovation, there are many independent entrepreneurs and many innovative ideas, and China is releasing the boundless vitality of economic development. Under the condition of developing a socialist market economy, the relationship between individual and individual, individual and society is also varied, not all of them are commodity exchange relations[8]. In various sectors of the country's development, social welfare, precision poverty alleviation, medical care, education and other areas of gain and loss cannot be simply calculated with money. Economic and social development not only needs the guarantee of the system but also needs the individual to raise consciousness. Therefore, it is necessary to cultivate the service spirit of selfless dedication in the process of cultivating mass entrepreneurship and innovation talents.

\section{CONCLUSION}

The decision made by the Party Central Committee and the State Council to build an innovative country is a major strategic decision concerning the overall situation of socialist modernization. The development of society needs the promotion of the individual, the individual development cannot be separated from the support of the society, and the personal development and the future and destiny of the country are dependent on each other. Cultivating mass entrepreneurship and innovation talents are the need for building an innovative country and the need for personal development. The strength of the spirit of Beidahuang is the spiritual support for the cultivation of innovative talents.

To learn and integrate the spirit of Beidahuang in the cultivation of entrepreneurship and innovation talents, it is to let young people understand the hardships of China's development history in the process of realizing the spirit of Beidahuang; it is to enable young people to grow up to remember the original ideals and aspirations, to forge ahead; is to achieve the great rejuvenation of the Chinese nation Chinese Dream to build cultural support, cohesion of spiritual motivation [9]. The quality of Painstaking efforts. Daring to open up Pay attention to the interest of the whole, selfless dedication" is important to the cultivation of mass entrepreneurship and innovation talent training in universities of China. The good thought quality and the firm and indomitable work style may enhance the youth overall accomplishment, to let the new generation of young people be the trendsetter in the wave of innovation and entrepreneurship revolution.

\section{ACKNOWLEDGEMENTS}

This work was supported by General Research Projects on Higher Education and Teaching Reform in Heilongjiang Province (SJGY20190482), Teaching Research Project of Review and evaluation of Heilongjiang Bayi Agricultural University (NDJY1801), The Doctoral Scientific Research Start-up Foundation of Heilongjiang Bayi Agricultural University of China (No. XYB2014-04), Youth Special Project in the 13th Five-Year Plan of Education Science in Heilongjiang Province (GJD1318025).

\section{REFERENCES}

1. Xi JP. Building a Well-off Society in an All-round Way and Winning the Great Victory of Socialism with Chinese Characteristics in the New Era -Report at the 19th National Congress of the Communist Party of China. Beijing: People's Publishing House. 2017.

2. Yan KX. "Mass entrepreneurship and innovation" is not without the word "crowd". Economic Daily. 2015-08-11.

3. Yan DD. Local Aesthetics and Cultural Perspectives in the Literature of the Beidahuang Corps. Magazine Office of Study \& Exploration. 2014, (7): 144.

4. Chen T. Headstream of Jinping Xi's Ideology is the Years of Educated Urban Youth Working in the Countryside, Journal of Construction of Old Areas. 2017, (4): 19-20.

5. Guo SY, Liu DY. The Unfading Spirit of Beidahuang. Journal of Xinyang Agriculture and Forestry University. 2019, (2): 8-11.

6. Wang CH. The Spirit and Contemporary Value of the Beidahuang. Journal of Heilongjiang Institute of Socialism. 2010, (3): 51-53.

7. The governance of China with Xi Jinping (II). Bei Jing: Foreign Languages Press in China. 2017, 142 143.

8. $\mathrm{Xu} \mathrm{KF}$. The spirit of Beidahuang to further develop and promote. Farms and Land Reclamation administration of China. 2017, (05): 46.

9. Chen YY, Li J. The Spirit and Contemporary Value of the Beidahuang. Journal of Daqing Normal University. 2019, (5): 100-106. 